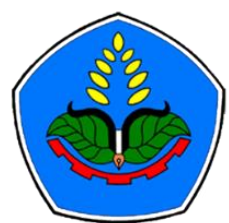

AGROPROSS

National Conference

Proceedings of Agriculture

\section{Proceedings:}

Peningkatan Produktivitas Pertanian Era Society 5.0 Pasca Pandemi

Tempat : Politeknik Negeri Jember

Tanggal : 22 Juli 2021

Publisher :

Agropross, National Conference Proceedings of Agriculture

ISBN : 978-623-94036-6-9

DOI : 10.25047 /agropross.2021.229

\title{
Pertumbuhan Dan Produksi Benih 14 Varietas Bawang Merah (Allium Cepa L. Var Aggregatum) di Dataran Tinggi Lembang, Kabupaten Bandung Barat
}

\author{
Author(s): Nurmalita Waluyo ${ }^{(1)^{*}}$, Joko Pinilih ${ }^{(1)}$, Ineu Sulastrini ${ }^{(1)}$, Eli Korlina \\ Edisaputra $^{(1)}$ \\ (1) Balai Penelitian Tanaman Sayuran Jln, Tangkuban Perahu No, 517, Lembang, Bandung \\ * Corresponding author: nurmalitawaluyo@gmail.com
}

\section{ABSTRACT}

Shallots are the main commodity in Indonesia that are used as cooking spices and medicines, so their availability throughout the year is very important to meet these needs. This study aims to determine the growth and seed production of 14 shallot varieties in the highlands. The study was conducted to determine the growth and yield of shallots in Margahayu Experimental Garden Indonesian Vegetables Research Institute (IVEGRI) Lembang (1,250 $\mathrm{m}$ asl) from August to October 2020. The materials used are 14 varieties of shallots from Indonesian Agency for Agricultural Research and Development (IAARD), namely: Sembrani, Maja Cipanas, Bima Brebes, Kuning, Trisula, Mentes, Kramat 1, Violetta 1 Agrihorti, Violetta 2 Agrihorti, Violetta 3 Agrihorti, Ambassador 1 Agrihorti, Ambassador 2 Agrihorti, Ambassador 3 Agrihorti, and Ambassador 4 Agrihorti. The growth of 14 shallot varieties during planting was good. Ambassador 3 Agrihorti showed the highest plant height and leaf length compared to other varieties, which were $41.80 \mathrm{~cm}$ and $34.72 \mathrm{~cm}$, respectively. Seed weight per clump ranged from 31.00-64.61 grams. Violetta 2 Agrihorti showed the highest number of bulb per clump, wet weight per clump, dry weight of eskip bulb per clump, and the highest seed weight per clump compared to other varieties, which were 9.70 bulbs; 144.53 grams, 85.69 grams, and 31.59 grams, respectively. Meanwhile, the highest seed weight per plot was found in the Sembrani variety. The growth and production of shallot seeds are influenced by the variety.
\end{abstract}

Keywords:

Growth;

seed production;

shallots;

highlands

\section{Kata Kunci: ABSTRAK}

Pertumbuhan; Bawang merah merupakan komoditas utama di Indonesia yang digunakan sebagai bumbu masak dan obat, sehingga ketersediaannya sepanjang tahun sangat penting untuk mencukupi kebutuhan produksi benih; tersebut. Penelitian bertujuan untuk mengetahui pertumbuhan dan produksi benih 14 varietas bawang merah di dataran tinggi. Penelitian dilakukan untuk mengetahui pertumbuhan dan hasil bawang merah; dataran tinggi. bawang merah di KP. Margahayu Balai Penelitian Tanaman Sayuran (Balitsa) Lembang (1.250 m dpl) dari bulan Agustus s.d. Oktober 2020. Materi yang digunakan berupa 14 varietas bawang merah dari Badan Penelitian dan pengembangan Pertanian (Balitbangtan), yaitu: Sembrani, Maja Cipanas, Bima Brebes, Kuning, Trisula, Mentes, Kramat 1, Violetta 1 Agrihorti, Violetta 2 Agrihorti, Violetta 3 Agrihorti, Ambassador 1 Agrihorti, Ambassador 2 Agrihorti, Ambassador 3 Agrihorti, dan Ambassador 4 Agrihorti. Pertumbuhan 14 varietas bawang merah selama penanaman cukup baik. Ambassador 3 Agrihorti menunjukkan tinggi tanaman dan panjang daun tertinggi dibanding varietas lainnya, yaitu masing-masing $41,80 \mathrm{~cm}$ dan $34,72 \mathrm{~cm}$. Berat benih per rumpun berkisar antara 31,00-64,61 gram. Violetta 2 Agrihorti menunjukkan jumlah umbi per rumpun, berat basah per rumpun, berat kering eskip umbi per rumpun, dan berat benih per rumpun tertinggi dibanding varietas lainnya, yaitu masing-masing 9,70 umbi; 144,53 gram, 85,69 gram dan 31,59 gram. Sedangkan berat benih per plot tertinggi terdapat pada varietas Sembrani. Pertumbuhan dan produksi benih bawang merah dipengaruhi oleh varietas. 


\section{PENDAHULUAN}

Bawang merah merupakan komoditas utama di Indonesia yang digunakan sebagai bumbu masak dan obat, sehingga ketersediaannya sepanjang tahun sangat penting untuk mencukupi kebutuhan tersebut. Luas lahan bawang merah setiap tahun juga mengalami peningkatan dari 156,779 hektar pada tahun 2018, menjadi 159,195 hektar pada tahun 2019 atau meningkat $1.54 \%$ (Kementan, 2021). Dengan meningkatnya luas tanam bawang merah setiap tahun, maka kebutuhan benih pun akan meningkat.

Kebutuhan benih bermutu sangat menentukan keberhasilan budidaya tanaman, karena potensi genetik suatu tanaman akan diperoleh ketika benih yang digunakan merupakan benih bermutu. Balai Penelitian Tanaman Sayuran (Balitsa) dari tahun 1980 s.d. 2019 telah merilis 22 varietas unggul bawang merah. Untuk memenuhi kebutuhan benih varietas-varietas tersebut, setiap tahun dilakukan produksi benih sumber. Produksi benih sumber ini menempati posisi strategis dalam industri perbenihan nasional, karena menjadi sumber bagi produksi benih kelas dibawahnya yang akan digunakan oleh petani Adapun yang termasuk benih sumber yaitu benih inti, benih penjenis, benih dasar dan benih pokok (Kementan, 2011). Salah satu benih sumber yang diproduksi di Balitsa yaitu benih inti. Benih inti ini dapat digunakan untuk memproduksi benih kelas penjenis atau kelas dibawahnya.

Lembang yang berada di Kab. Bandung Barat memiliki rata-rata suhu lebih rendah dan kelembaban udara yang tinggi. Hal ini mempengaruhi pertumbuhan dan perkembangan tanaman. Pengaruh faktor lingkungan ini berpengaruh secara kumulatif terhadap fase pertumbuhan dan perkembangan tanaman (Nur, Azrai, \& Trikoesoemaningtyas, 2016). Hasil merupakan karakter kompleks yang dipengaruhi oleh karakter pertumbuhan dan komponen hasil (Nasution, 2010). Penelitian bertujuan untuk mengetahui pertumbuhan dan produksi benih 14 varietas bawang merah di dataran tinggi Lembang, Kabupaten Bandung Barat.

\section{METODOLOGI}

Penelitian dilakukan untuk mengetahui pertumbuhan dan produksi benih bawang merah di KP. Margahayu Balitsa Lembang $(1.250 \mathrm{~m} \mathrm{dpl})$ dari bulan Agustus s.d. Oktober 2020. Materi yang digunakan berupa 14 varietas bawang merah dari Badan Penelitian dan pengembangan Pertanian (Balitbangtan), yaitu: Sembrani, Maja Cipanas, Bima Brebes, Kuning, Trisula, Mentes, Kramat 1, Violetta 1 Agrihorti, Violetta 2 Agrihorti, Violetta 3 Agrihorti, Ambassador 1 Agrihorti, Ambassador 2 Agrihorti, Ambassador 3 Agrihorti, dan Ambassador 4 Agrihorti.

Setiap varietas ditanam dalam 1 (satu) plot dengan ukuran $1,1 \mathrm{~m} \mathrm{x} 14 \mathrm{~m}$ (lebar x panjang), terdiri dari 465 lubang tanam dengan jarak $20 \times 15 \mathrm{~cm}$. Benih yang digunakan merupakan hasil produksi benih inti yang dipanen pada bulan April 2020. Penanaman dilakukan pada 6 Agustus 2020, dan panen pada tanggal 15 Oktober 2020 (70 HST).

Pemupukan menggunakan pupuk kandang ayam $\left(15 \mathrm{t} \mathrm{ha}^{-1}\right)$, dolomit $\left(1,5 \mathrm{tha}^{-}\right.$ $\left.{ }^{1}\right)$, pupuk TSP $46\left(250 \mathrm{~kg} \mathrm{ha}^{-1}\right)$, diberikan sebelum tanam sebagai pupuk dasar. Pupuk susulan diberikan pada 2, 4 dan 6 minggu setelah tanam (MST) berupa larutan pupuk NPK 16.16.16 pada konsentrasi $8 \mathrm{~g}^{-1}$ sebanyak $100 \mathrm{ml}$ tanaman $^{-1}$. Selain itu juga dilakukan pemupukan menggunakan $\mathrm{KCl}$ White dengan cara disemprotkan pada konsentrasi $2 \mathrm{~g} \mathrm{l}^{-1}$ pada umur 3, 5 dan 7 MST. Pengendalian hama dan penyakit dilakukan dengan penyemprotan pestisida sesuai dengan OPT yang menyerang. 
Pengairan dan penyiangan dilakukan sesuai dengan stadia pertumbuhan.

Sampel tanaman setiap varietas untuk pengamatan pertumbuhan dan komponen hasil sebanyak 10 tanaman. Karakter yang diamati meliputi karakter pertumbuhan: tinggi tanaman $(\mathrm{cm})$, panjang daun $(\mathrm{cm})$, jumlah anakan, jumlah daun per rumpun; komponen hasil: diameter umbi (mm), tinggi umbi (mm), jumlah umbi per rumpun, berat umbi basah per rumpun $(\mathrm{g})$, berat umbi kering per rumpun $(\mathrm{g})$, berat umbi benih per rumpun $(\mathrm{g})$, susut bobot basah-kering umbi (\%), susut bobot basah-benih umbi (\%), susut bobot kering-benih umbi (\%); hasil umbi basah per plot $(\mathrm{kg})$, hasil umbi kering per plot $(\mathrm{kg})$, hasil umbi benih per plot $(\mathrm{kg})$. Pengamatan penunjang berupa suhu, kelembaban dan curah hujan selama pengujian serta pengamatan penyakit.

\section{HASIL DAN PEMBAHASAN Kondisi Umum}

Kondisi umum pertanaman cukup baik. Kondisi cuaca saat penelitian memasuki pancaroba. Penanaman dilakukan pada awal bulan Agustus dimana curah hujan sangat kecil dengan jumlah hari hujan hanya sebanyak 3 hari, dan total hari hujan sampai panen (dasarian kedua bulan Oktober) hanya 14 hari hujan. Dan saat panen cuaca memasuki musim hujan. Rata-rata suhu udara, suhu udara maksimal, suhu udara minimal, kelembaban udara dan jumlah curah hujan selama pengujian dari bulan Agustus s.d. Oktober 2021 masing-masing berkisar antara $21,17-23,97{ }^{0} \mathrm{C}$; 24,20-26,25 ${ }^{0} \mathrm{C}$; $15,15-16,35{ }^{0} \mathrm{C} ; 84,67-89,21 \%, 72,20-$ $389,30 \mathrm{~mm}$ (Tabel 1).

Tabel 1. Suhu, kelembaban dan curah hujan selama pengujian bawang merah

\begin{tabular}{lllrrrrc}
\hline \multicolumn{1}{c}{ Bulan } & Dasarian & Suhu & Suhu Max & Suhu Min & RH (\%) & Hujan & Jumlah hari hujan \\
\hline Agustus & 1 & 21,18 & 24,50 & 14,90 & 88,70 & 26,5 & 1 \\
& 2 & 20,98 & 25,20 & 15,20 & 88,90 & 70 & 2 \\
& 3 & 21,35 & 25,36 & 15,36 & 89,55 & 0 & 0 \\
\hline Rata-rata Agustus & & 21,17 & 25,02 & 15,15 & 89,05 & & \\
\hline Jumlah Agustus & & & & & & 96,50 & 3 \\
\hline September & 1 & 22,80 & 28,10 & 16,10 & 91,90 & 0 & 0 \\
& 2 & 22,90 & 27,00 & 17,50 & 92,10 & 0 & 0 \\
& 3 & 20,09 & 23,64 & 15,45 & 83,64 & 72,2 & 4 \\
\hline Rata-rata September & & 21,93 & 26,25 & 16,35 & 89,21 & & \\
\hline Jumlah September & & & & & & 72,20 & 4 \\
\hline Oktober & 1 & 24,10 & 24,40 & 15,40 & 85,50 & 97,5 & 4 \\
& 2 & 24,30 & 24,20 & 15,20 & 85,50 & 42,3 & 3 \\
& 3 & 23,50 & 24,00 & 15,00 & 83,00 & 249,5 & 10 \\
\hline Rata-rata Oktober & 23,97 & 24,20 & 15,20 & 84,67 & & \\
\hline Jumlah Oktober & & & & & 389,30 & 17 \\
\hline
\end{tabular}

Tabel 2 menunjukkan karakter pertumbuhan 14 varietas bawang merah yang terdiri dari karakter tinggi tanaman, panjang daun, jumlah anakan per rumpun dan jumlah daun per rumpun. Setiap varietas menunjukkan pertumbuhan yang beragam. Tinggi tanaman berkisar antara 28,45-43,42 cm. Bima brebes merupakan varietas dengan tinggi tanaman terendah dan Ambassador 2 Agrihorti varietas dengan tinggi tanaman tertinggi. Klon dan tipe pertumbuhan bawang merah berpengaruh terhadap tinggi tanaman (Hidayat, Putrasameja, \& Azmi, 2011). Panjang daun berkisar antara 23,00-34,72 $\mathrm{cm}$. Panjang daun dipengaruhi oleh 
lingkungan dan musim di lokasi pertanaman (Hidayat et al., 2011).

Jumlah anakan per rumpun berkisar antara 4,20-8,000 dan jumlah daun per rumpun $23,80-48,65$ helai. Peningkatan jumlah daun akan meningkatkan akumulasi fotosintat yang akan digunakan dalam mendukung perkembangan umbi (Sulistyaningsih et al., 2020; Firmansyah and Bhermana, 2019). Jumlah daun dan jumlah anakan akan mempengaruhi jumlah umbi (Kusmana, Basuki, \& Kurniawan, 2009). Menurut Waluyo (2021) jumlah umbi per rumpun berkorelasi positif dengan jumlah anakan dan jumlah daun per rumpun dan berkorelasi negatif dengan ukuran umbi. Hal ini menunjukkan semakin banyak jumlah anakan dan jumlah daun maka jumlah umbi semakin banyak, tetapi semakin sedikit jumlah umbi per rumpun, ukuran umbi akan semakin besar.

Tabel 2. Keragaan karakter pertumbuhan 14 varietas bawang merah

\begin{tabular}{lcccc}
\hline Varietas & $\begin{array}{c}\text { Tinggi } \\
\text { tanaman } \\
(\mathrm{cm})\end{array}$ & $\begin{array}{c}\text { Panjang } \\
\text { daun }(\mathrm{cm})\end{array}$ & $\begin{array}{c}\text { Jumlah } \\
\text { anakan }\end{array}$ & $\begin{array}{c}\text { Jumlah } \\
\text { daun }\end{array}$ \\
\hline Sembrani & 36,90 & 29,60 & 4,20 & 23,80 \\
Maja Cipanas & 30,15 & 23,20 & 7,45 & 42,00 \\
Bima Brebes & 28,45 & 23,00 & 8,00 & 41,80 \\
Kuning & 32,00 & 26,15 & 7,50 & 38,15 \\
Trisula & 31,00 & 24,40 & 6,00 & 32,75 \\
Mentes & 34,85 & 28,90 & 4,25 & 24,95 \\
Kramat-1 & 35,75 & 30,20 & 6,40 & 28,10 \\
Violetta 1 Agrihorti & 41,10 & 31,25 & 5,45 & 30,95 \\
Violetta 2 Agrihorti & 38,05 & 30,50 & 7,90 & 48,65 \\
Violetta 3 Agrihorti & 33,95 & 27,35 & 7,00 & 35,15 \\
Ambassador 1 Agrihorti & 30,80 & 25,05 & 6,15 & 30,80 \\
Ambassador 2 Agrihorti & 43,42 & 34,72 & 5,95 & 35,90 \\
Ambassador 3 Agrihorti & 41,80 & 34,72 & 7,75 & 42,15 \\
Ambassador 4 Agrihorti & 38,95 & 30,30 & 6,95 & 31,40 \\
\hline Rerata & 35,51 & 28,52 & 6,50 & 34,75 \\
\hline
\end{tabular}

Tabel 3 menunjukkan karakter komponen hasil 14 varietas bawang merah. Setiap varietas menunjukkan karakter komponen hasil yang beragam. Jumlah umbi per rumpun berkisar antara 4,909,70, diameter umbi 22,04-32,02 $\mathrm{mm}$, tinggi umbi 25,88-31,61 $\mathrm{mm}$. Dari tiga karakter ini terlihat varietas Sembrani memiliki ukuran umbi terbesar, tetapi jumlah umbi per rumpun paling sedikit. Menurut Kusmana et al. (2009) bawang merah dengan ukuran umbi besar mungkin memiliki jumlah anakan yang lebih sedikit. Jumlah umbi lebih banyak dipengaruhi oleh faktor genetik dan lebih sedikit oleh faktor lingkungan (Budianto et al., 2009; Firmansyah and Bhermana, 2019).
Karakter komponen hasil berupa berat basah umbi per rumpun, berat kering umbi per rumpun dan berat benih per rumpun, masing-masing berkisar antara 77,91-144,53 gram, 48,95-85,69 gram, dan 31,00-64,61 gram. Berat basah, kering dan benih umbi per rumpun setiap varietas beragam, tergantung dari susut bobot setiap varietasnya. Produktivitas bawang merah dipengaruhi oleh karakter jumlah umbi yang dicerminkan dengan banyaknya jumlah anakan serta berat umbi yang dihasilkan (M. A. Firmansyah, 2018).

Susut bobot yang terendah merupakan susut bobot yang terbaik, semakin rendah susut bobot semakin tinggi berat kering umbi dan berat benih umbi yang diperoleh. Berat kering umbi per 
rumpun merupakan berat umbi setelah disimpan sampai benih kering eskip umbi per rumpun kurang lebih 7-14 hari setelah panen tergantung dari kondisi ruang pengering, cuaca dan varietas. Berat benih per rumpun merupakan berat umbi per rumpun setelah disimpan kurang lebih 2 bulan setelah panen. Susut bobot basahkering, susut bobot basah-benih, dan susut bobot kering-benih masing-masing berkisar antara 31,59-47,77 \%, 53,50$67,70 \%$, dan $22,68-41,36 \%$. Violetta 2 Agrihorti merupakan varietas yang memiliki berat umbi tertinggi dan susut bobot basah-kering umbi terendah dibandingkan varietas lainnya. Varietas yang berbeda memberikan nilai susut bobot yang berbeda pula (Azmi, Hidayat, \& Wiguna, 2011)

Tabel 3. Keragaan karakter komponen hasil 14 varietas bawang merah

\begin{tabular}{|c|c|c|c|c|c|c|c|c|c|}
\hline Varietas & $\begin{array}{l}\text { Jumlah } \\
\text { umbi } \\
\text { per } \\
\text { rumpun }\end{array}$ & $\begin{array}{l}\text { Diameter } \\
(\mathrm{mm})\end{array}$ & $\begin{array}{l}\text { Tinggi } \\
(\mathrm{mm})\end{array}$ & $\begin{array}{l}\text { Berat } \\
\text { basah } \\
\text { umbi } \\
\text { per } \\
\text { rumpun } \\
(\mathrm{g})\end{array}$ & $\begin{array}{l}\text { Berat } \\
\text { kering } \\
\text { umbi } \\
\text { per } \\
\text { rumpun } \\
\text { (g) }\end{array}$ & $\begin{array}{l}\text { Berat } \\
\text { benih } \\
\text { per } \\
\text { rumpun } \\
\quad(\mathrm{g})\end{array}$ & $\begin{array}{l}\text { Susut } \\
\text { bobot } \\
\text { basah- } \\
\text { kering } \\
(\%)\end{array}$ & $\begin{array}{c}\text { Susut } \\
\text { bobot } \\
\text { basah- } \\
\text { benih } \\
(\%)\end{array}$ & $\begin{array}{c}\text { Susut } \\
\text { bobot } \\
\text { kering } \\
\text {-benih } \\
(\%)\end{array}$ \\
\hline Sembrani & 4,90 & 32,02 & 31,61 & 116,13 & 78,33 & 47,63 & 32,00 & 59,01 & 39,21 \\
\hline Maja Cipanas & 7,40 & 24,49 & 27,52 & 99,83 & 56,68 & 41,23 & 43,27 & 58,93 & 27,79 \\
\hline Bima Brebes & 9,50 & 22,06 & 25,88 & 78,59 & 48,95 & 31,00 & 37,07 & 60,56 & 36,63 \\
\hline Kuning & 6,55 & 26,00 & 27,52 & 113,44 & 60,89 & 45,65 & 46,13 & 60,26 & 25,98 \\
\hline Trisula & 7,55 & 22,04 & 26,87 & 77,91 & 46,05 & 33,62 & 39,60 & 56,97 & 27,90 \\
\hline Mentes & 6,60 & 23,51 & 27,35 & 102,71 & 55,14 & 42,50 & 45,28 & 58,78 & 23,18 \\
\hline Kramat-1 & 6,05 & 25,71 & 27,76 & 101,49 & 57,95 & 43,35 & 42,06 & 57,34 & 25,29 \\
\hline Violetta 1 Agrihorti & 7,05 & 25,59 & 29,26 & 133,38 & 75,60 & 56,57 & 42,72 & 57,57 & 25,22 \\
\hline Violetta 2 Agrihorti & 9,70 & 23,99 & 26,70 & 144,53 & 85,69 & 64,61 & 31,59 & 55,27 & 24,28 \\
\hline Violetta 3 Agrihorti & 8,95 & 24,88 & 27,11 & 122,40 & 73,52 & 56,91 & 39,69 & 53,50 & 22,68 \\
\hline Ambassador 1 Agrihorti & 7,30 & 23,96 & 27,03 & 82,23 & 51,95 & 38,13 & 35,43 & 53,92 & 27,15 \\
\hline Ambassador 2 Agrihorti & 6,65 & 27,15 & 29,22 & 131,20 & 77,10 & 55,40 & 40,75 & 57,72 & 28,30 \\
\hline Ambassador 3 Agrihorti & 6,60 & 23,52 & 27,13 & 118,95 & 61,91 & 45,37 & 47,77 & 62,04 & 27,17 \\
\hline Ambassador 4 Agrihorti & 7,90 & 24,96 & 28,70 & 143,29 & 78,86 & 46,67 & 44,74 & 67,70 & 41,36 \\
\hline Rerata & 7,34 & 24,99 & 27,83 & 111,86 & 64,90 & 46,33 & 40,58 & 58,54 & 28,72 \\
\hline
\end{tabular}

Tabel 4 menunjukkan karakter hasil 14 varietas bawang merah. Karakter hasil merupakan hasil per plot dengan luas bersih $15,4 \mathrm{~m}^{2}$. Dari luas yang sama setiap varietas menunjukkan hasil yang cukup beragam. Hasil merupakan karakter kuantitatif yang sangat dipengaruhi oleh lingkungan. Berat basah umbi per plot berkisar antara 12,78-40,06 $\mathrm{kg}$, berat kering umbi per plot 7,46-22,02 kg dan berat benih umbi per plot 3,34-17,91 kg. Ambassador 2 Agrihorti merupakan varietas yang menunjukkan berat basah dan kering umbi per plot tertinggi dibanding varietas lainnya. Hal ini menunjukkan varietas ini cocok untuk ditanam pada musim pancaroba, dimana suhu udara pada saat pertumbuhan cukup tinggi dan curah hujan cukup rendah, sedangkan saat panen curah hujan cukup tinggi. Penanaman bawang merah yang baik umunya dilakukan pada akhir musim hujan dan panen pada awal musim kemarau.

Varietas-varietas selain Ambassador 2 Agrihorti, varietas yang menunjukkan berat basah umbi per plot dan berat kering umbi per plot diatas ratarata saat pengujian $(25,61 \mathrm{~kg}$ dan 22,02 $\mathrm{kg})$, yaitu varietas Sembrani $(34,87 \mathrm{~kg}$ dan $20,55 \mathrm{~kg}$ ), Kuning (28,00 kg dan 15,08 kg), Violetta 1 Agrihorti (27,33 kg dan 14,76 
$\mathrm{kg})$, Violetta 2 Agrihorti $(32,45 \mathrm{~kg}$ dan $17,86 \mathrm{~kg})$, Ambassador 3 Agrihorti $(36,42$ $\mathrm{kg}$ dan $17,07 \mathrm{~kg})$, dan Ambassador 4 Agrihorti $(31,93 \mathrm{~kg}$ dan $15,79 \mathrm{~kg})$. Tujuh varietas ini dapat dikatakan adaptif di musim pancaroba, dataran tinggi Lembang, Kab. Bandung Barat karena mampu memberikan hasil yang cukup tinggi.

Sembrani merupakan varietas yang menghasilkan berat benih umbi per plot paling tinggi, yaitu 17,91 kg. Dibandingkan Ambassador 2 Agrihorti yang menghasilkan berat basah dan berat kering umbi per plot yang tertinggi, Sembrani dapat menghasilkan berat benih tertinggi dapat disebabkan oleh susut bobot yang rendah dibandingkan Ambassador 2 Agrihorti. Menurut Ayu, Rauf, \& Samudin (2016) pengaruh varietas berpengaruh nyata terhadap pertumbuhan dan hasil bawang merah. Potensi hasil suatu varietas tergantung pada lingkungan tumbuhnya (Dewi, Sobir, \& Syukur, 2015).

Tabel 4. Produksi benih 14 varietas bawang merah

\begin{tabular}{lccc}
\hline Varietas & $\begin{array}{c}\text { Berat basah umbi per } \\
\text { plot } 15,4 \mathrm{~m}^{2}(\mathrm{~kg})\end{array}$ & $\begin{array}{l}\text { Berat kering umbi } \\
\text { per plot } 15,4 \mathrm{~m}^{2}(\mathrm{~kg})\end{array}$ & $\begin{array}{c}\text { Berat benih umbi per } \\
\text { plot } 15,4 \mathrm{~m}^{2}(\mathrm{~kg})\end{array}$ \\
\hline Sembrani & 34,87 & 20,55 & 17,91 \\
Maja Cipanas & 20,00 & 11,57 & 7,41 \\
Bima Brebes & 12,79 & 7,49 & 4,31 \\
Kuning & 28,00 & 15,08 & 12,86 \\
Trisula & 12,78 & 7,46 & 3,34 \\
Mentes & 20,79 & 11,01 & 8,56 \\
Kramat-1 & 23,08 & 13,19 & 9,89 \\
Violetta 1 Agrihorti & 27,33 & 14,76 & 10,57 \\
Violetta 2 Agrihorti & 32,45 & 17,86 & 12,65 \\
Violetta 3 Agrihorti & 20,22 & 11,74 & 9,57 \\
Ambassador 1 Agrihorti & 17,82 & 10,52 & 8,38 \\
Ambassador 2 Agrihorti & 40,06 & 22,02 & 15,05 \\
Ambassador 3 Agrihorti & 36,42 & 17,06 & 12,67 \\
Ambassador 4 Agrihorti & 31,93 & 15,79 & 11,47 \\
\hline Jumlah & 358,55 & 196,08 & 144,63 \\
\hline Rerata & 25,61 & 14,01 & 10,33 \\
\hline
\end{tabular}

Penyakit yang menyerang tanaman bawang merah antara lain, bercak ungu/trotol (Alternaria porii), Antraknos/otomatis (Colletotrichum), busuk umbi Fusarium dan busuk putih Sclerotum, busuk daun Stemphylium dan virus (Sutrisno, 2015). Pengamatan terhadap penyakit Alternaria porri (Gambar 1), antraknos , stemphllium (Gambar 2), dan downy mildew (Gambar 3) dilakukan dari minggu ke 3 s.d. 9 MST. Intensitas serangan penyakit Alternaria porri berkisar antara 0-21,54\%, dengan intensitas serangan tertinggi pada 5 MST. Faktor cuaca berperan penting pada pemencaran konidium harian jamur Alternaria porii dan intensitas penyakit bercak ungu. Penyakit ini dipengaruhi oleh suhu, kelembaban relatif dan kecepatan angin. Pada suhu udara dan kecepatan angin tinggi dan kelembaban relatif rendah pemencaran konidium mencapai maksimal (Hadisutrisno, Sudarmadi, Subandiyah, \& Priyatmojo, 1996). Penyakit A. porri dapat 
menyerang di musim kemarau maupun musim penghujan (Korlina, Sulastrini, \& Hermanto, 2020).

Penyakit Antraknos pada penelitian ini hanya menyerang varietas Ambassador 1 Agrihorti pada 5 MST dengan intensitas serangan penyakit 3,08\%. Gejala khas penyakit antraknos berupa daun yang melekuk, berlekuk dan klorosis dan panjang leher daun yang tidak normal dan intensitas penyakit paling tinggi pada umur 5 MST dan paling rendah 2 MST. Penyakit antraknos pada bawang merah dapat dijumpai pada berbagai umur tanaman dan periode hujan berpengaruh terhadap intensitas penyakit (Hadisutrisno, 1999).

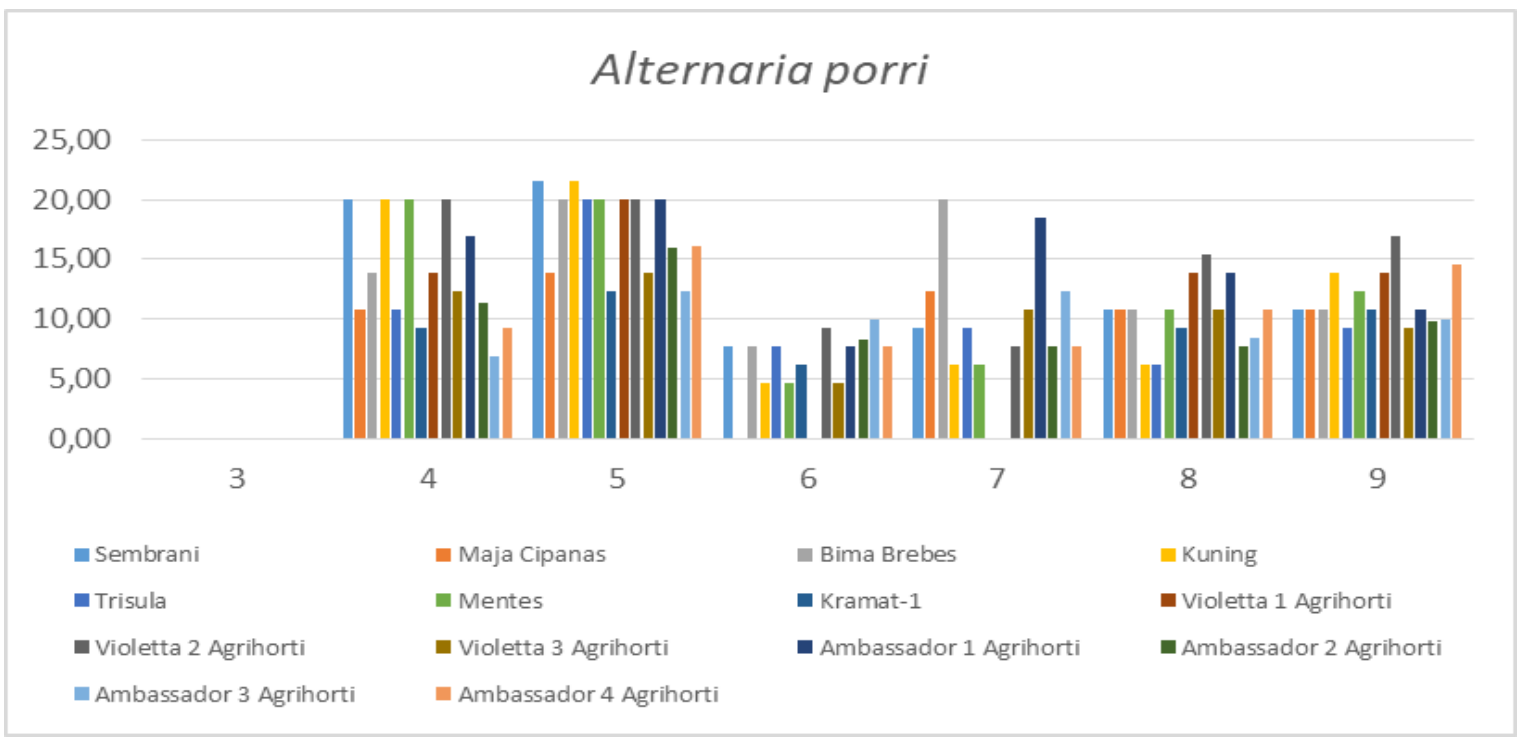

Gambar 1. Intensitas serangan penyakit Alternaria porri pada pertanaman bawang merah di pada 3 s.d. 9 MST, 2020

Intensitas serangan penyakit Sthemphyllium berkisar antara 0-23,08 \%, dengan intensitas serangan tertinggi pada 5 MST. Hasil penelitian Suheri \& Price (2001) pada bawang daun gejala pertama Alternaria porri terjadi pada daun yang lebih tua, 54-69 hari setelah tanam. Lesi dengan gejala khas dikolonisasi oleh Alternaria porri (6\%), Stemphylium vesicarium $(42 \%)$ atau campuran kedua patogen $(52 \%)$. Penyakit Stemphylium, yang serius menyerang daun, tangkai daun dan tangkai bunga bawang merah. Pada umumnya gejala serangan kedua penyakit tersebut sering terjadi pada daun tua. Penyakit A. porri dan S. vesicarium akan selalu muncul di pertanaman bawang merah dengan serangan sedang sampai berat, apabila kondisi cuaca mendukung dan tidak dikendalikan.(Korlina et al., 2020). 


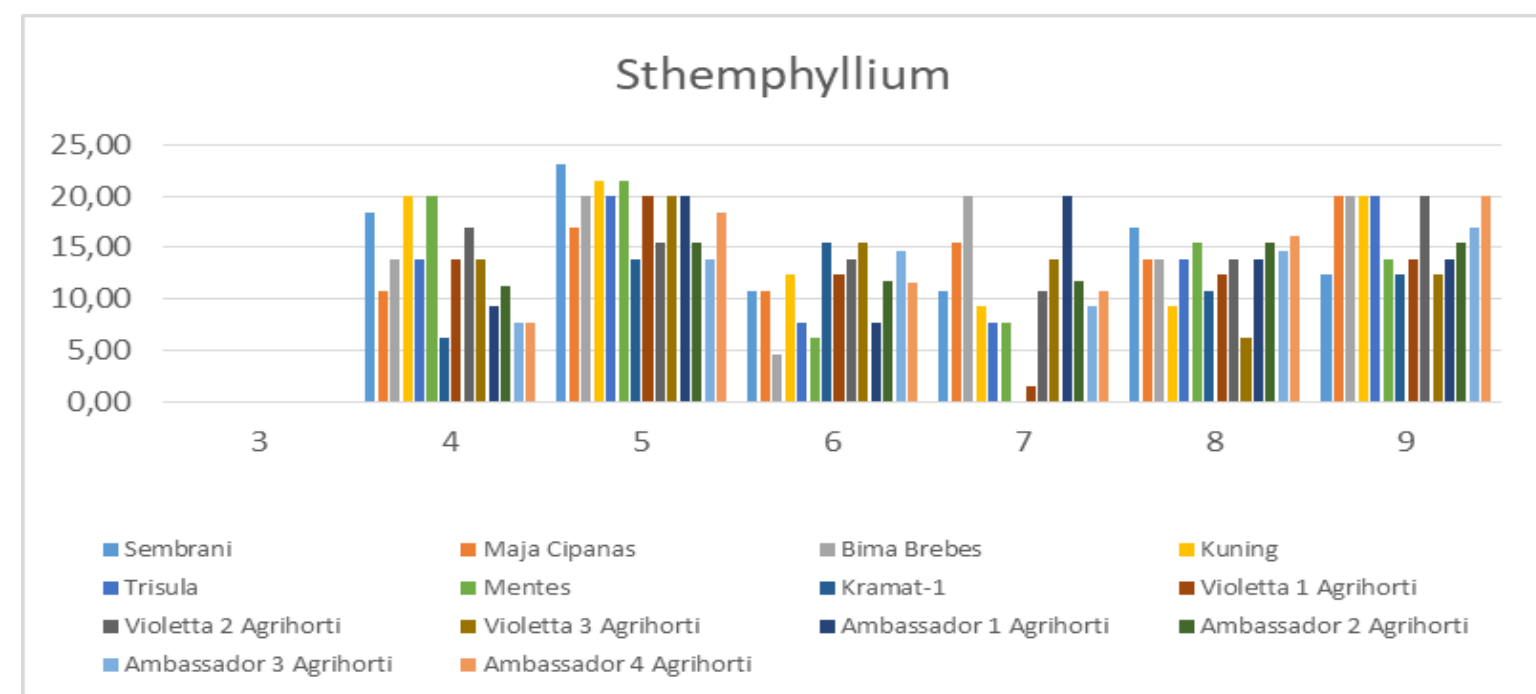

Gambar 2. Intensitas serangan penyakit Sthemphyllium pada pertanaman bawang merah di pada 3 s.d. 9 MST, 2020

Penyakit downy mildew disebabkan oleh cendawan Peronospora destructor (Berk.) Casp. Pada kondisi yang lembab, berkabut atau curah hujan tinggi, cendawan akan membentuk masa spora yang sangat banyak, yang terlihat sebagai bulu-bulu halus berwarna ungu (violet) yang menutupi daun bagian luar dan batang (umbi) (Udiarto K., Setiawati, \& Suryaningsih, 2005). Pada penelitian ini intensitas serangan penyakit downy mildew berkisar antara 0-21,54 \%, dengan intensitas serangan tertinggi pada 5 MST. Penyakit ini dapat menyerang pada berbagai umur tanaman.

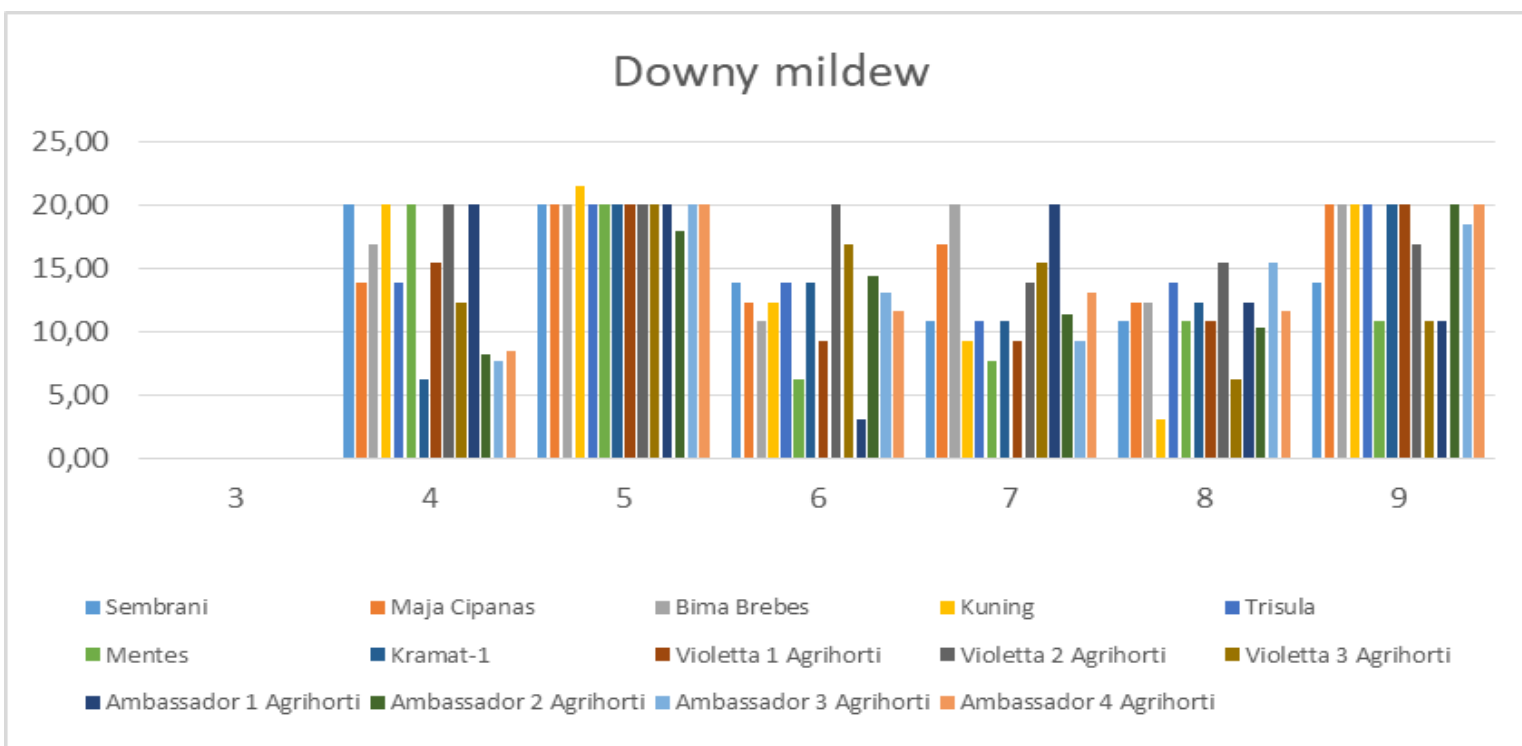

Gambar 3. Intensitas serangan penyakit Downy mildew pada pertanaman bawang merah di pada 3 s.d. 9 MST, 2020

\section{KESIMPULAN}

Pertumbuhan dan produksi benih 14 varietas bawang merah yang ditanam di
Lembang, Kab. Bandung Barat menunjukkan hasil yang beragam pada setiap karakter yang diamati. Tinggi tanaman dan panjang daun tertinggi 
terdapat pada varietas Ambassador 2 Agrihorti. Komponen hasil berupa jumlah umbi per rumpun, berat basah umbi per rumpun, berat kering umbi per rumpun, dan berat benih per rumpun tertinggi terdapat pada varietas Violetta 2 Agrihorti dan produksi benih berupa berat benih umbi per plot tertinggi terdapat pada varietas Sembrani dengan hasil $17,91 \mathrm{~kg}$ dengan luas plot $15,4 \mathrm{~m}^{2}$.

\section{ACKNOWLEDGEMENT}

Terima kasih kepada Badan Litbang Pertanian yang telah membiayai kegiatan ini melalui DIPA Balitsa TA.2021 dan seluruh pihak yang telah membantu kegiatan ini.

\section{SUMBER DANA PENELITIAN}

Kegiatan ini didanai oleh DIPA Balitsa kode kegiatan 1804.408.051.B.2 Tahun 2020.

\section{DAFTAR PUSTAKA}

Ayu, N. G., Rauf, A., \& Samudin, S. (2016). Pertumbuhan dan Hasil Dua Varietas Bawang Merah (Allium ascalonicum L.) pada berbagai Jarak Tanam. E-J.Agrotekbis, 4(5), 530 536.

Azmi, C., Hidayat, I. M., \& Wiguna, G. (2011). Pengaruh Varietas dan Ukuran Umbi terhadap Produktivitas Bawang Merah. Jurnal Hortikultura, 21(3), 206-213.

Budianto, A., Ngawit, \& Sudika. (2009). Keragaman Genetik Beberapa Sifat dan Seleksi Klon Berulang Sederhana pada Tanaman Bawang Merah Kultivar Ampenan. Crop Agro, 2(1), $1-5$.

Dewi, S. M., Sobir, \& Syukur, M. (2015). Interaksi Genotipe $\mathrm{x}$ Lingkungan Hasil dan Komponen Hasil 14 Genotipe Tomat di Empat Lingkungan Dataran Rendah. Jurnal Agronomi Indonesia, 43(1), 59-65.

Firmansyah, A., \& Bhermana, A. (2019).
The Growth, Production, and Quality of Shallot at Inland Quartz Sands (Quarzipsamments) in The Off Season. Ilmu Pertanian (Agricultural Science), 4(3), 110.

Firmansyah, M. A. (2018). Pertumbuhan, Produksi, dan Kualitas Bawang Merah di Tanah Pasir Kuarsa Pedalaman Luar Musim. Jurnal Agroekoteknologi FP USU, 6(2), 271-278.

Hadisutrisno, B. (1999). Peranan Faktor Lingkungan terhadap Penyakit Antraknos pada Bawang Merah. Jurnal Perlindungan Tanaman Indonesia, 5(1), 20-23.

Hadisutrisno, B., Sudarmadi, Subandiyah, S., \& Priyatmojo, A. (1996). Peranan Faktor Cuaca terhadap Infeksi dan Perkembangan Penyakit Bercak Ungu pada Bawang Merah. Indonesian Journal Plant Protection, 1(1), 5664.

Hidayat, I. ., Putrasameja, S., \& Azmi, C. (2011). Persiapan Pelepasan Varietas Bawang Merah Umbi dan TSS. Laporan Kegiatan. Balai Penelitian Tanaman Sayuran.

Korlina, E., Sulastrini, I., \& Hermanto, C. (2020). Efektivitas Fungisida Difenokonazol dan Tebukonazol terhadap Pertumbuhan Cendawan Alternaria Porri dan Stemphylium Vesicarium pada Tanaman Bawang Merah Secara In Vitro. Prosiding Seminar Nasional Pertanian Peternakan Terpadu Ke-3, 8-14.

Kusmana, Basuki, R., \& Kurniawan, H. (2009). Uji Adaptasi Lima Varietas Bawang Merah Asal Dataran Tinggi dan Medium pada Ekosistem Dataran Rendah Brebes. J. Hort., 19(3), 281286.

Nasution, M. A. (2010). Analisis Korelasi dan Sidik Lintas Antara Karakter Morfologi dan Komponen Buah Tanaman Nenas (Ananas comosus L. Merr.). Crop Agro, 3(1), 1-8. 
Nur, A., Azrai, M., \& Trikoesoemaningtyas. (2016). Interaksi Genetik x Lingkungan dan Variabilitas Genetik Galur Gandum Introduksi (Triticum aestivum L.) di Agroekosistem Tropika. Jurnal AgroBiogen, 10(3), 93-100.

Suheri, H and T.V. Price. (2001). The epidemiology of purple leaf blotch on leeks in Victoria, Australia. European Journal of Plant Pathology 107: 503-510

Sulistyaningsih, E., Pangestuti, R., \& Rosliani, R. (2020). Growth and Yield of Five Prospective Shallot Selected Accessions from True Seed of Shallot in Lowland Areas. Ilmu Pertanian (Agricultural, 5(2), 92-97.

Sutrisno. (2015). Faktor-Faktor Lingkungan yang Mempengaruhi Pengembangan Budidaya Bawang Merah (Allium Ascalonicum, sp) di Kabupaten Pati. Jurnal Litbang, 11(2), 93-102. https://doi.org/10.33658/j1.v11i2.65

Udiarto K., B., Setiawati, W., \& Suryaningsih, E. (2005). Pengenalan Hama dan Penyakit pada Tanaman Bawang Merah dan Pengendaliannya.

Waluyo, N. (2020). Parameter Genetik, Korelasi, Interaksi $\mathrm{G} X \mathrm{E}$, dan Analisis Stabilitas Hasil, Komponen Hasil, serta Karakter Pertumbuhan 12 Genotipe Bawang Merah (Allium cepa L. Var Aggregatum) di Tiga Lokasi Dataran Tinggi. Tesis. Universitas Padjadjaran. Bandung. 182 hal. 